Dominik SIEKLUCKI

Uniwersytet Jagielloński

dominik.sieklucki@uj.edu.pl

\title{
ZMIANY I PROJEKTY ZMIAN W POLSKIM SYSTEMIE WYBORCZYM PO UCHWALENIU KODEKSU WYBORCZEGO
}

\section{ABSTRACT Polish electoral system in the process of change}

The article is the critical examination of changes in the polish electoral system after codification in 2011 year. Author analyses all changes in electoral law since 5 January 2011 and all draft bills which have been submitted to the Marshall of the Sejm in two last terms. The most important aims of the article are the answers the questions about reasons, premises and purposes of the changes and draft bills. Author also identify three types of changes in electoral system - adjustments, reforms and modernizations - and tries to show basic threats and problems connected with changes in electoral law.

Słowa kluczowe: system wyborczy, prawo wyborcze, wybory, zmiana

Keywords: electoral system, electoral law, elections, change 
5 stycznia 2011 r. Sejm RP uchwalił Kodeks wyborczy ${ }^{1}$, realizując zgłaszane od drugiej połowy lat $90 . \mathrm{XX}$ w. projekty i postulaty kodyfikacji prawa wyborczego ${ }^{2}$. Jedną z najważniejszych przyczyn kodyfikacji było dążenie do stabilizacji prawa wyborczego ${ }^{3}$, tzn. ograniczenia praktyki wprowadzania zbyt częstych zmian, towarzyszących zazwyczaj konkretnym wyborom i świadczących o instrumentalnym wykorzystywaniu systemu wyborczego przez partie polityczne do doraźnych celów walki politycznej (wyborczej) $)^{4}$. Praktykę tę trafnie podsumował Andrzej Sokala w komentarzu do ordynacji do Sejmu i Senatu RP z 12 kwietnia 2001 r. słowami zachowującymi nadal dużą aktualność: kolejne wybory - kolejna ordynacja ${ }^{5}$. Jej potwierdzeniem mogą być również dane dotyczące wprowadzanych zmian w Kodeksie wyborczym - od dnia jego uchwalenia do 9 listopada 2015 r. (w tym dniu kończyła się kadencja Sejmu wybranego w 2011 r.), czyli w okresie około czterech lat i dziesięciu miesięcy, zgłoszono 36 projektów ustaw nowelizujących jego przepisy, z których 14 uchwalono. Ponadto w pierwszych pięciu miesiącach działania Sejmu VIII kadencji do Marszałka Sejmu wpłynęły dwa projekty zmian w Kodeksie wyborczym.

Dokonywanie zmian w Kodeksie wyborczym średnio co 137 dni oraz zgłaszanie projektów zmian statystycznie co 50 dni w okresie prawie 61 miesięcy (licząc od daty uchwalenia Kodeksu do dnia 5 kwietnia 2016 r.) oznacza, że polski system wyborczy daleki jest od stabilizacji, a Kodeks nie osiągnął przywołanego powyżej celu. Dane arytmetyczne stanowią również podstawę do sformułowania trzech celów badawczych niniejszego artykułu. Po pierwsze, udzielenia odpowiedzi na pytanie, jakie były główne założenia i cele zgłaszanych projektów zmian w Kodeksie wyborczym, przy czym moim zamierzeniem nie jest szczegółowe analizowanie wszystkich regulacji, co z uwagi na objętość artykułu nie jest możliwe, ale dokonanie ich syntetycznej charakterystyki i pogrupowanie w spójne merytorycznie kategorie, pozwalające uchwycić zasadnicze tendencje w procesie wprowadzania zmian w systemie wyborczym III RP. Po drugie, sformułowanie wyjaśnienia, dlaczego kodyfikacja nie wpłynęła na stabilizację prawa wyborczego. Trzeci problem badawczy to przedstawienie wniosków i spostrzeżeń odnoszących się do przyszłości polskiego systemu wyborczego, zarówno tej najbliższej (po wyborach parlamentarnych 2015 r.), jak i długofalowej. Można bowiem postawić tezę,

Ustawa z dnia 5 stycznia 2011 r. - Kodeks wyborczy, Dz.U. 2011, nr 21, poz. 112.

2 K. Skotnicki, Przebieg prac nad kodeksem wyborczym, [w:] Kodeks wyborczy. Wstępna ocena, red. tenże, Warszawa 2011, s. 12-14.

3 Oprócz stabilizacji prawa wyborczego kodyfikacja miała osiągnąć również dwa inne cele - umieszczenie wszystkich przepisów w jednym dokumencie miało uczynić prawo wyborcze łatwiejszym w stosowaniu oraz kodyfikacja miała w założeniu przynieść rozstrzygnięcie szeregu wyzwań stojących przed rozwiązaniami wyborczymi, np. związanych z wdrażaniem e-votingu lub wprowadzaniem ułatwień dla obywateli. D. Sieklucki, Dynamika systemu wyborczego III Rzeczypospolitej na tle historycznym, Kraków 2015, s. 179.

4 A. Patrzałek, W. Skrzydło, Cele i zasady kodyfikacji prawa wyborczego w Polsce, „Przegląd Sejmowy” 1997, nr 2(19), s. 11.

5 A. Sokala, Ordynacja wyborcza do Sejmu Rzeczypospolitej Polskiej i do Senatu Rzeczypospolitej Polskiej $z$ dnia 12 kwietnia 2001 r. - wstęp i krótki komentarz, Toruń 2001, s. 11. 
że tendencje i procesy dotyczące zmian w systemie wyborczym występujące w Sejmach VI i VII kadencji były w jakimś sensie typowe dla polskiego systemu politycznego i zapewne będą one kontynuowane.

Ze względu na to, że celem artykułu jest dokonanie analizy aktualnych zagadnień związanych z polskim systemem wyborczym, pomijam w nim problematykę zmian systemu wyborczego w okresie przed uchwaleniem Kodeksu wyborczego. Przedmiotem analizy są wszystkie projekty ustaw wprowadzające zmiany w Kodeksie zgłoszone w Sejmie RP VI i VII kadencji, przy czym szczególną uwagę poświęcam projektom, które nie zostały uchwalone $e^{6}$. Projekty ustaw stanowią bowiem nie tylko wartościową bazę empiryczną umożliwiającą wyodrębnienie głównych tendencji zmian w systemie wyborczym, ale również pozwalają na ograniczenie analizy do pomysłów i koncepcji o konkretnie zarysowanym charakterze. Trzeba bowiem zauważyć, że projekt ustawy, aby mógł zostać wniesiony do Marszałka Sejmu, musi być sporządzony w odpowiedniej formie i musi posiadać szereg określonych w Regulaminie pierwszej izby elementów uzupełniających, takich jak wyjaśnienie celu i potrzeby wydania ustawy, wskazanie różnic między stanem rzeczywistym a przedstawionym w projekcie czy określenie przewidywanych skutków społecznych, gospodarczych, finansowych i prawnych uchwalenia ${ }^{7}$. Tym samym poza zakresem rozważań pozostawiam pomysły zmian w systemie wyborczym, które do końca kadencji Sejmu RP upływającej w 2015 r. nie przybrały takiej postaci. Najbardziej znaną inicjatywą tej kategorii był projekt wprowadzenia w Polsce jednomandatowych okręgów wyborczych (tzw. JOW) w wyborach do Sejmu ${ }^{8}$, będący jednym z haseł kampanii wyborczej na urząd Prezydenta RP i przedmiotem referendum z 6 września 2015 r. ${ }^{9}$

Łączna analiza 36 projektów ustaw nowelizujących Kodeks wyborczy pozwala na wyodrębnienie trzech zasadniczych kategorii zmian, które umownie określam jako:

$6 \quad$ W analizie nie uwzględniam propozycji zmian w Kodeksie wyborczym zgłaszanych w Sejmie VIII kadencji. W ciągu pierwszych niespełna pięciu miesięcy jego działania (od 10 XI 2015 r. do 5 IV 2016 r.) do Marszałka Sejmu, jak wspomniałem, wpłynęły dwa projekty zmian zgłoszone przez opozycję. Odnoszę się do nich na końcu artykułu. Zamknięcie rozważań na końcu kadencji Sejmu upływającej w dniu 9 XI 2015 r. uzasadniam klarownością analizy oraz stanowiskiem, że dorobek parlamentu należy badać po zakończeniu kadencji, gdyż wtedy można uzyskać całościowy, spójny obraz prac legislacyjnych. Czas działania Sejmu VIII kadencji jest bowiem zbyt krótki, dorobek legislacyjny zbyt mały i przyszłość w niewielkim stopniu przewidywalna, by można na jego podstawie formułować daleko idące wnioski.

7 Obwieszczenie Marszatka Sejmu Rzeczypospolitej Polskiej z dnia 17 stycznia 2012 r. w sprawie ogtoszenia jednolitego tekstu uchwaty Sejmu Rzeczypospolitej Polskiej - Regulamin Sejmu Rzeczypospolitej Polskiej, M.P. 2012, poz. 32.

8 W stosunku do postulatu wprowadzenia w Polsce JOW należy odnotować dwie uwagi ogólne. Po pierwsze, postulat ten odnosi się wyłącznie do Sejmu RP, co oznacza, że jego realizacja nie jest możliwa bez zmiany art. 96 ust. 2 Konstytucji RP zawierającego zasadę proporcjonalności. Po drugie, wprowadzenie JOW wymaga rozstrzygnięcia wielu szczegółowych kwestii związanych m.in. ze zgłaszaniem kandydatów, wyborem większości wymaganej do zdobycia mandatu czy w końcu podjęcia decyzji, czy ma to być prosty system wzorowany na rozwiązaniach brytyjskich, czy też bardziej skomplikowany system wyborczy, np. w postaci STV.

9 Postanowienie Prezydenta Rzeczypospolitej Polskiej z dnia 17 czerwca 2015 r. o zarzadzeniu ogólnokrajowego referendum, Dz.U. 2015, poz. 852. 
„korekta”, „reforma” i „modernizacja”. Liczbę zmian i projektów zmian z podziałem na poszczególne kategorie przedstawia tab. 1.

Określenie „korekta”, wywodzące się z języka łacińskiego ${ }^{10}$, dosłownie rozumiane jako poprawianie lub usuwanie błędów ${ }^{11}$, w odniesieniu do systemu wyborczego oznacza wprowadzanie modyfikacji o charakterze formalnym, niezmieniających trybu wyboru określonych instytucji i w niewielkim (lub żadnym) stopniu wpływających na przebieg procesu wyborczego. Natomiast pojęcie „reformy” zgodnie ze słownikowym znaczeniem tego terminu ${ }^{12}$ oznacza przekształcenie lub przebudowanie o znaczącym jakościowo charakterze. W tej grupie umieszczam zmiany, których konsekwencje można łatwo zauważyć lub przewidzieć, modyfikujące w istotny sposób przebieg procesu wyborczego i mające zasadniczo celowy charakter w tym znaczeniu, że o ile „korekty” wynikały z zewnętrznych (obiektywnych) wobec ustawodawcy przyczyn, o tyle propozycje "reform” wynikały z oceny określonego stanu rzeczy i były ukierunkowane na jego zmianę. Ostatnie z zaproponowanych określeń: „modernizacja” jest pojęciem stosunkowo ogólnym, łączonym $w$ ujęciu etymologicznym ${ }^{13} \mathrm{z}$ unowocześnianiem. Na potrzeby artykułu przyjmuję, że odnosi się ono do trzech powiązanych ze sobą kwestii modernizacja to wprowadzenie nowego i zarazem istotnego rozwiązania do systemu wyborczego, ukierunkowanego na osiągnięcie pozytywnych efektów, które mogą być jednak stwierdzone w dłuższej perspektywie czasowej. Stąd „modernizacja” oznacza zasadniczo doniosłą jakościowo zmianę o charakterze systemowym.

Tabela 1. Projekty zmian w Kodeksie wyborczym zgłoszone w Sejmie VI i VII kadencji

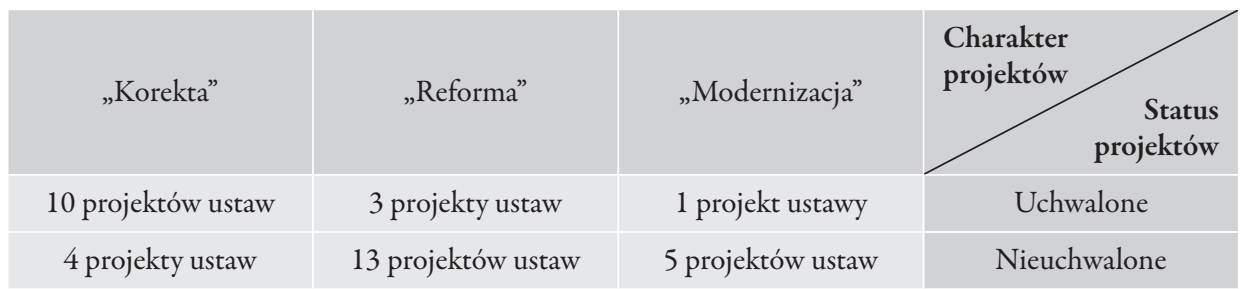

Źródło: opracowanie własne.

10 korekta, [w:] Stownik wyrazów obcych i zwrotów obcojęzycznych Wtadystawa Kopalińskiego, [online] http://www.slownik-online.pl/kopalinski/743361D15E06F5F3C12565E9005557E1.php, $20 \times 2015$.

11 korekta, [w:] Stownik jezyka polskiego PWN, [online] http://sjp.pwn.pl/sjp/korekta;2474027.html, $20 \times 2015$.

12 reforma, [w:] Stownik wyrazów obcych i zwrotów obcojezycznych Wtadystawa Kopalińskiego, [online] http://www.slownik-online.pl/kopalinski/2EAFA44F187E7CE9C12565850074CCB9.php, 20 X 2015; reforma, [w:] Stownik jezyka polskiego PWN, [online] http://sjp.pwn.pl/szukaj/reforma.html, $20 \times 2015$.

13 modernizacja, [w:] Stownik wyrazów obcych i zwrotów obcojezycznych Wtadystawa Kopalińskiego, [online] http://www.slownik-online.pl/kopalinski/F065D59D113D2D41C12565DB005AFA8E.php, 20 X 2015; modernizacja, [w:] Stownik jezyka polskiego PWN, [online] http://sjp.pwn.pl/szukaj/modernizacja.html, 20 X 2015. 
Jako uzupełnienie danych zawartych w powyższej tabeli należy dodać, że na 22 nieuchwalone projekty składa się 6 odrzuconych na różnych etapach postępowania legislacyjnego, 5 wycofanych przez wnioskodawców i 11, nad którymi podjęto prace, lecz nie zostały one zakończone w Sejmie VII kadencji. Ponadto z 12 uchwalonych nowelizacji 4 zostały przyjęte przez Sejm RP VI kadencji.

Przechodząc do charakterystyki kierunków zmian w polskim systemie wyborczym opartej na powyższej kategoryzacji, warto poczynić jeszcze jedną uwagę organizującą dalsze rozważania. Tak duża liczba projektów zmian nie oznacza, że każda z nich stanowiła odrębną kategorię, ale wprost przeciwnie - niektóre pokrywały się co do zakresu regulacji i mogą być traktowane łącznie.

Dla czytelności analizy oraz dla egzemplifikacji wyodrębnionych powyżej kategorii zmian w systemie wyborczym rozważania rozpoczynam od przedstawienia modyfikacji wprowadzonych do Kodeksu wyborczego.

W pierwszej ze wskazanych grup umieszczam łącznie 10 uchwalonych zmian w Kodeksie wyborczym. Dwie z nich polegały na skorygowaniu podziałów na okręgi wyborcze w wyborach do Sejmu w $2011^{14}$ i 2015 r. $^{15}$ wynikających ze stosowania jednolitej normy przedstawicielstwa i zmian w liczbie mieszkańców w niektórych okręgach wyborczych. Wprowadzenie pięciu polegało na dostosowaniu Kodeksu wyborczego do innych regulacji prawnych: uchwalona 26 maja $2011 \mathrm{r}^{16}$ nowelizacja wynikała z modyfikacji przepisów ustawy o samorządzie gminnym dotyczących procedury dokonywania zmian w podziale administracyjnym państwa; ustawą z 13 lipca $2012 \mathrm{r}^{17}$ nałożono na ministra właściwego ds. budownictwa obowiązek ustalenia warunków technicznych lokalu wyborczego dostosowanego do potrzeb osób niepełnosprawnych; 12 października 2012 r. ${ }^{18}$ dostosowano do wyroku Trybunału Konstytucyjnego przepisy Kodeksu wyborczego dotyczące zarządzania wyborów; zmiana z 23 listopada 2012 r. $^{19}$ była efektem szerszych działań legislacyjnych dostosowujących polskie regulacje rynku usług pocztowych do przepisów prawa Unii Europejskiej ${ }^{20}$; a nowelizacja z 10 stycznia $2014 \mathrm{r}^{21}$ wdrażała regulacje prawa UE w zakresie korzystania z biernego prawa wyborczego przez obywateli Unii w wyborach do Parlamentu Europejskiego. Natomiast pozostałe trzy zmiany miały charakter poprawek lub uzupełnień przepisów Kodeksu -

14 Ustawa z dnia 1 kwietnia 2011 r. o zmianie ustawy - Ordynacja wyborcza do Sejmu Rzeczypospolitej Polskiej i do Senatu Rzeczypospolitej Polskiej oraz ustawy - Kodeks wyborczy, Dz.U. 2011, nr 94, poz. 550.

15 Ustawa z dnia 10 lipca 2015 r. o zmianie ustawy - Kodeks wyborczy, Dz.U. 2015, poz. 1044.

16 Ustawa z dnia 26 maja 2011 r. o zmianie ustawy o samorzadzie gminnym oraz niektórych innych ustaw, Dz.U. 2011, nr 134, poz. 777.

17 Ustawa z dnia 13 lipca 2012 r. o zmianie ustawy o dziatach administracji rządowej oraz niektórych innych ustaw, Dz.U. 2012, poz. 951.

18 Ustawa z dnia 12 października 2012 r. o zmianie ustawy - Przepisy wprowadzające ustawe - Kodeks wyborczy, Dz.U. 2012, poz. 1399.

19 Ustawa z dnia 23 listopada 2012 r. Prawo pocztowe, Dz.U. 2012, poz. 1529.

20 Rzadowy projekt ustawy - Prawo pocztowe, Sejm RP, VII kadencja, Druk nr 801, Warszawa, 8 X 2012, s. 122.

21 Ustawa z dnia 10 stycznia 2014 r. o zmianie ustawy - Kodeks wyborczy, Dz.U. 2014, poz. 179. 
15 kwietnia $2011 \mathrm{r}^{22}$ doprecyzowano i uzupełniono przepisy związane z kampanią wyborczą; 31 sierpnia $2011 \mathrm{r}^{23}$ zmieniono podmiot uprawniony do stwierdzania wygaśnięcie mandatu wójta (burmistrza, prezydenta miasta); a 10 stycznia 2014 r. ${ }^{24}$ poprawiono przepisy dotyczące wydatków na kampanię wyborczą w wyborach do Parlamentu Europejskiego.

Natomiast zmiany o charakterze „reform” wprowadzono do Kodeksu wyborczego tylko trzykrotnie. Sejm RP VI kadencji 3 lutego $2011 \mathrm{r}^{25}$ (a więc niespełna miesiąc od uchwalenia Kodeksu i przed jego wejściem w życie) wydał nowelizację zakazującą emitowania płatnych ogłoszeń wyborczych w prasie, radiu i telewizji. Jak tłumaczyli wnioskodawcy, celem zakazu jest ograniczenie zjawiska mediatyzacji kampanii wyborczych oraz odciążenie partii politycznych od konieczności gromadzenia wysokich sum na kampanię wyborczą ${ }^{26}$. Warto nadmienić, że nowelizacja ta została uchylona przez Trybunał Konstytucyjny ${ }^{27} \mathrm{z}$ powodu niezgodności z Konstytucją $a^{28}$. Celem drugiej zmiany uchwalonej 27 maja $2011 \mathrm{r}^{29}$ - było wprowadzenie ułatwień dla osób niepełnosprawnych w postaci m.in. głosowania przez pełnomocnika, głosowania korespondencyjnego czy korzystania z nakładek na karty do głosowania sporządzonych w alfabecie Braille’a. Trzecia zmiana została wprowadzona w Kodeksie wyborczym 25 czerwca 2015 r. ${ }^{30}$ Jest to stosunkowo obszerna nowelizacja przygotowana pod wpływem doświadczeń z wyborów do organów jednostek samorządu terytorialnego przeprowadzonych w $2014 \mathrm{r}$. i zmierzająca do usprawnienia procesu przeprowadzania wyborów. Najistotniejsze zmiany wiązały się ze stosunkowo wysokim odsetkiem nieważnych głosów oddanych 16 listopada 2014 r. (przykładowo w wyborach do sejmików województw oddano 17,47\% nieważnych głosów $\left.{ }^{31}\right) . Z$ tego powodu m.in. na obwodowe komisje wyborcze nałożono obowiązek ustalania i podawania w protokołach przyczyn nieważności głosów, wójtów (burmistrzów, prezydentów miast) zobligowano do rozsyłania wyborcom najpóźniej na

22 Ustawa z dnia 15 kwietnia 2011 r. o zmianie ustawy - Kodeks wyborczy oraz ustawy - Przepisy wprowadzające ustawe - Kodeks wyborczy, Dz.U. 2011, nr 102, poz. 588.

23 Ustawa z dnia 31 sierpnia 2011 r. o zmianie ustawy - Kodeks wyborczy oraz niektórych innych ustaw, Dz.U. 2011, nr 217, poz. 1281.

24 Ustawa z dnia 10 stycznia 2014 r. o zmianie ustawy - Kodeks wyborczy, Dz.U. 2014, poz. 180. Ustawa z dnia 3 lutego 2011 r. o zmianie ustawy - Kodeks wyborczy, Dz.U. 2011, nr 26, poz. 134.

26 Poselski projekt ustawy o zmianie ustawy - Kodeks wyborczy oraz ustawy Przepisy wprowadzajace ustawe - Kodeks wyborczy, Sejm RP, VI kadencja, Druk nr 3813, Warszawa, 14 I 2011, s. 4.

Wyrok Trybunatu Konstytucyjnego z dnia 20 lipca 2011 r. sygn. akt K 9/11, Dz.U.2011, nr 149, poz. 889.

Trybunał Konstytucyjny, uchylając nowelizację, zwrócił uwagę, że naruszyła ona zawartą w art. 2 Konstytucji zasadę demokratycznego państwa prawnego poprzez wprowadzenie istotnej zmiany do prawa wyborczego w okresie 6 miesięcy przed wyborami. Tamże, s. 59-60.

29 Ustawa z dnia 27 maja 2011 r. o zmianie ustawy - Kodeks wyborczy oraz ustawy Przepisy wprowadzajace ustawe - Kodeks wyborczy, Dz.U. 2011, nr 147, poz. 881.

Ustawa z dnia 25 czerwca 2015 r. o zmianie ustawy - Kodeks wyborczy, Dz.U. 2015, poz. 1043.

31 Wybory samorządowe 2014 r. Statystyki wyników głosowania, [online] http://pkw.gov.pl/wizualizacja-wyborow-samorzadowych-samorzad-2014/wybory-samorzadowe-2014-r-statystyki-wynikow-glosowania.html, 20 X 2015. 
21 dni przed głosowaniem zbiorczych informacji o wyborach, w tym sposobie głosowania, oraz zmodyfikowano formę kart do głosowania.

Do Kodeksu wyborczego wprowadzono również jedną zmianę o charakterze modernizacyjnym. Nowelizacja z 11 lipca 2014 r. przyniosła bowiem możliwość głosowania korespondencyjnego w wyborach wszystkich instytucji z wyjątkiem organów jednostek samorządu terytorialnego. Jak wspomniałem, sama instytucja głosowania za pośrednictwem poczty została wprowadzona wcześniej - z takiego udogodnienia mogli korzystać wyborcy niepełnosprawni oraz (co przewidziano w pierwotnej wersji Kodeksu) wyborcy głosujący w obwodach utworzonych za granicą, jednak dopiero powyższa nowelizacja rozszerzyła to uprawnienie na wszystkich wyborców. $Z$ tego powodu dopiero tę zmianę uznaję za modernizacyjną, gdyż wcześniejsze regulacje w tym zakresie dotyczyły stosunkowo nielicznych grup wyborców i zmierzały do ułatwienia im uczestnictwa w akcie głosowania. Przyznanie tego uprawnienia wszystkim wyborcom jak wynika nie tylko z uzasadnienia projektu ${ }^{32}$, ale też literatury przedmiotu ${ }^{33}-\mathrm{w}$ założeniu było ukierunkowane na osiągnięcie pozytywnego efektu w postaci zwiększenia frekwencji wyborczej. Wprawdzie pierwsze wybory, w których można było głosować za pośrednictwem poczty, nie przyniosły dużego zainteresowania tą formą głosowania ${ }^{34}$, ale być może z czasem stanie się ona bardziej popularna.

Drugą wyszczególnioną w tabeli grupę zmian stanowią propozycje, które zostały zgłoszone w formie projektów ustaw (wniesionych do Marszałka Sejmu), jednak nie zostały uchwalone. Stanowią one bardzo wartościowy przedmiot analizy, ponieważ na ich podstawie można wskazać możliwe kierunki zmian w systemie wyborczym. Są one przejawem różnorodnych pomystów i propozycji modyfikacji w systemie wyborczym, które wprawdzie w ujęciu formalnym mają charakter historyczny z uwagi na zasadę dyskontynuacji prac parlamentu, ale można je również traktować albo jako wyraz pewnych trwałych tendencji występujących w polskim systemie politycznym, albo zapowiedź działań, jakie mogą zostać podjęte w przyszłości. Na szczególne podkreślenie zasługuje duża liczba projektów umieszczona w grupie zmian o charakterze „reform” i „modernizacji”.

Warto również zauważyć, że w syntetycznym ujęciu w przypadku 6 projektów prace zakończyły się ich odrzuceniem w głosowaniach, 4 zostały wycofane, a prace nad 12 nie zostały zakończone. Szczegółowe dane zawarte w tab. 2 będą przedmiotem

32 Poselski projekt ustawy o zmianie ustawy - Kodeks wyborczy oraz niektórych innych ustaw, Sejm RP, VII kadencja, Druk nr 1786, Warszawa, 24 VII 2013, s. 16.

33 J.Zbieranek, Alternatywne procedury gtosowania w polskim prawie wyborczym-gwarancja powszechności wyborów czy mechanizm zwiększania frekwencji wyborczej?, Warszawa 2013, s. 22-23.

34 W pierwszej turze wyborów prezydenckich $10 \mathrm{~V} 2015$ r. zamiar oddania głosu za pośrednictwem poczty wyraziło 42814 osób, a głosowało 35053 osoby. W drugiej turze $24 \mathrm{~V} 2015$ r. liczby te wynosiły odpowiednio: 56845 i 40620 osób. Oznacza to, że korespondencyjnie oddano około 0,002\% wszystkich głosów. Obwieszczenie Państwowej Komisji Wyborczej z dnia 11 maja 2015 r. o wynikach gtosowania $i$ wyniku wyborów Prezydenta Rzeczypospolitej Polskiej, zarządzonych na dzień 10 maja 2015 r., Dz.U. 2015, poz. 650; Obwieszczenie Państwowej Komisji Wyborczej z dnia 25 maja 2015 r. o wynikach ponownego gtosowania i wyniku wyborów Prezydenta Rzeczypospolitej Polskiej, Dz.U. 2015, poz. 725 . 
analizy w dalszej części tekstu, należy jednak w tym miejscu sformułować dwie uwagi ogólne. Po pierwsze, do interpretacji danych o formalnym statusie projektów należy podchodzić z dużą ostrożnością, ponieważ nie zawsze oddają one ich stan faktyczny. Przykładowo - w odniesieniu do projektu wniesionego 30 października 2013 r. ${ }^{35}$ Komisja Nadzwyczajna ds. zmian w kodyfikacjach zarekomendowała jego odrzucenie ${ }^{36}$, ale do głosowania w tej sprawie nie doszło, a projekt zgłoszony 22 lutego $2012 \mathrm{r}^{37} \mathrm{zo}^{36}$ stał wycofany, lecz nie było to efektem decyzji wnioskodawców, ale wygaśnięcia mandatów grupy posłów po wyborach samorządowych 2014 r., które spowodowało obniżenie liczby posłów popierających projekt ustawy poniżej wymaganej liczby 15 osób. Po drugie, analiza prac legislacyjnych w Sejmie VII kadencji pozwala na stwierdzenie, że nieuchwalanie projektów zmian w prawie wyborczym wynikało z szeregu niekiedy niełatwo stwierdzalnych przyczyn. O ile odrzucanie lub wycofywanie projektów było efektem albo sprzeciwu wobec pewnych propozycji, albo konsekwencją obiektywnych przyczyn w postaci spadku liczby posłów popierających projekt, zgłaszanych w ekspertyzach i opiniach wątpliwości dotyczących formalnej strony nowelizacji czy powtarzania pewnych propozycji w różnych projektach ${ }^{38}$, o tyle niedokańczanie prac w większości przypadków wynikało z braku woli politycznej do ich sfinalizowania.

Tabela 2. Przebieg prac na projektami zmian w Kodeksie wyborczym w Sejmie RP VII kadencji

\begin{tabular}{|c|c|c|c|}
\hline & „Korekta” & „Reforma” & ”Modernizacja” \\
\hline Odrzucone projekty & 1 & 4 & 1 \\
\hline Wycofane projekty & 0 & 4 & 0 \\
\hline Prace niedokończone & 3 & 5 & 4 \\
\hline
\end{tabular}

Źródło: opracowanie własne.

Z punktu widzenia zmian w systemie wyborczym za najważniejsze należy uznać projekty zmian umieszczone w kategoriach „reforma” i „modernizacja”. Dla porządku warto jednak w skrócie scharakteryzować grupę pierwszą. Z czterech zgłoszonych projektów ustaw dwa odnosiły się do kwestii wygaśnięcia mandatów osób pełniących funkcje w organach jednostek samorządu terytorialnego: projekt z 22 marca 2012 r. ${ }^{39}$ przewidywał wygaśniecie mandatu radnego samorządowego z chwilą wyboru w po-

35 Poselski projekt ustawy o zmianie ustawy - Kodeks wyborczy, Sejm RP, VII kadencja, Druk nr 2019, Warszawa, 21 X 2013.

36 Sprawozdanie Komisji Nadzwyczajnej do spraw zmian w kodyfikacjach o poselskim projekcie ustawy o zmianie ustawy - Kodeks wyborczy, Sejm RP, VII kadencja, Druk nr 3088, Warszawa, 15 I 2015.

37 Poselski projekt ustawy o zmianie ustawy - Kodeks wyborczy, Sejm RP, VII kadencja, Druk nr 318, Warszawa, 22 II 2012.

38 Przykładowo projekt wniesiony 25 XI 2014 r. (druk nr 3053) został wycofany, ponieważ zakres proponowanych w nim zmian w dużym stopniu pokrywał się z regulacjami zawartymi w opisywanej nowelizacji uchwalonej 25 VI $2015 \mathrm{r}$.

39 Poselski projekt ustawy o zmianie ustawy - Kodeks wyborczy i niektórych innych ustaw, Sejm RP, VII kadencja, Druk nr 377, Warszawa, 22 III 2012. 
wszechnym głosowaniu na inną funkcję ${ }^{40}$, a projekt złożony 12 marca 2014 r. dotyczył procedury stwierdzania wygaśnięcia mandatu wójta (burmistrza, prezydenta miasta) w sytuacji trwałej niezdolności do pełnienia urzędu ${ }^{41}$. Projekt z 18 kwietnia 2013 r. wiązał się z dostosowywaniem przepisów Kodeksu wyborczego do wyroku Trybunału Konstytucyjnego z 18 lipca 2012 r. w zakresie składania skarg na niektóre decyzje organów wyborczych dotyczące rejestrowania komitetów wyborczych i list wyborczych ${ }^{42}$, a projekt z 15 maja 2015 r. ${ }^{43}$ zakładał, że dokumenty wyborcze muszą być przechowywane przez co najmniej pięć lat ${ }^{44}$.

W Sejmie RP VII kadencji aż 13 projektów ustaw zmierzało do reformy polskiego systemu wyborczego, przy czym można łatwo zauważyć, że dotyczyły one tylko trzech jego wymiarów: siedem projektów przewidywało reformę administracji wyborczej, sześć zakładało zmiany w systemie wyborczym do organów jednostek samorządu terytorialnego, a jeden odnosił się do problematyki prowadzenia kampanii wyborczej. Powyższa kategoryzacja obejmuje 14 propozycji, ponieważ jeden projekt zakładał jednocześnie reformę administracji wyborczej i sposobu wyboru organów samorządu terytorialnego.

W odniesieniu do projektów zmierzających do zreformowania administracji wyborczej łatwo można zauważyć, że zdecydowania większość z nich (łącznie pięć) została zgłoszona po wyborach samorządowych z 16 i 30 listopada 2014 r. i odnosiła się do problemów, które w nich wystąpiły. Awaria systemu informatycznego skutkująca znacznym opóźnieniem w ogłaszaniu wyniku wyborów, wysoki odsetek nieważnych głosów i wyniki sondaży exit poll rozmijające się z rzeczywistymi wynikami głosowania ${ }^{45}$ (szczególnie w odniesieniu do wyniku PSL) przyniosły wprost formułowane zarzuty o daleko idących manipulacjach w ustalaniu wyniku elekcji. Przykładowo Jarosław Kaczyński (PiS) 26 listopada 2014 r. podczas posiedzenia Sejmu mówił: z tej najważniejszej $w$ Polsce trybuny musza paść stowa prawdy: te wybory zostaty sfatszowane $e^{46}$, a w przeprowadzonych dzień wcześniej badaniach opinii publicznej (sondażu telefonicznym)

40 Projekt ten zmierzał do rozwiązania istotnego problemu, ponieważ, jak tłumaczyli wnioskodawcy, jego celem było wyeliminowanie praktyki politycznej polegającej na wystawianiu radnych samorządowych oraz osób pełniących funkcje wykonawcze w organach samorządu terytorialnego w wyborach innych instytucji (np. Sejmu lub PE) w celu zwiększenia poparcia dla list wyborczych. Osoby te później zrzekały się nowo zdobytego mandatu. Zob. tamże, s. 5-6.

${ }^{41}$ Poselski projekt ustawy o zmianie ustawy - Kodeks wyborczy i niektórych innych ustaw, Sejm RP, VII kadencja, Druk nr 2337, Warszawa, 12 III 2014.

42 Senacki projekt ustawy o zmianie ustawy - Kodeks wyborczy, Sejm RP, VII kadencja, Druk nr 1350, Warszawa, 18 IV 2013.

43 Poselski projekt ustawy o zmianie ustawy - Kodeks wyborczy, Sejm RP VII kadencja, Druk nr 3605, Warszawa, 15 V 2015.

44 Co ciekawe, w świetle obowiązujących przepisów dokumenty te zasadniczo są przechowywane bezterminowo, więc projekt ustawy prowadziłby do skrócenia okresu przechowywania, a wnioskodawcom, jak się wydaje, chodziło o wydłużenie tego okresu.

45 A. Rychard, Wprowadzenie, [w:] J. Flis i in., Co stato się 16 listopada? Wybory samorzadowe 2014 r., Warszawa 2015, s. 7.

46 Sprawozdanie stenograficzne $z$ 80. posiedzenia Sejmu RP $w$ dniu 26 listopada 2014 r., Warszawa 2014, s. 4. 
identyczną opinię wyraziło $25 \%$ respondentów ${ }^{47}$. Dlatego podstawowym elementem wspólnym wszystkich projektów z tej grupy było wprowadzanie rozwiązań mających na celu zwiększenie transparentności działania obwodowych komisji wyborczych lub (i) uzupełnienie obowiązujących wówczas procedur o mechanizmy przeciwdziałające wskazanym powyżej problemom. Należy również przypomnieć, że jedna z uchwalonych, przywołanych wcześniej nowelizacji dotyczyła tego zagadnienia.

Analiza sześciu wymienionych projektów pozwala zauważyć, że były one zgłaszane dość szybko w stosunku do daty wyborów samorządowych 2014 r. - dwa wniesiono do Marszałka Sejmu już w listopadzie, a ostatni 23 lutego 2015 r., oraz że cechowały się one stopniowo wzrastającą restrykcyjnością proponowanych rozwiązań. Zakres regulacji pierwszego projektu nowelizacji, wniesionego 25 listopada $2014 \mathrm{r}^{48}$, zasadniczo pokrywał się z uchwaloną 25 czerwca 2015 r., czyli zakładał zmianę formy kart do głosowania oraz obowiązek podawania w protokołach (oczywiście po uprzednim ustaleniu) przyczyn nieważności głosów. Natomiast projekt zgłoszony 27 listopada $2014 \mathrm{r}$. zakładał wydłużenie terminu składania protestów wyborczych z 14 do 30 dni, przy czym okres ten miałby być liczony od dnia ogłoszenia przez wojewódzkiego komisarza wyborczego wyników wyborów na obszarze województwa ${ }^{49}$, a nie, jak stanowi Kodeks wyborczy w art. 392 ust. 1, od dnia wyborów. Proponowaną zmianę uzasadniano opóźnieniami w ogłaszaniu wyników wyborów i tym samym skracaniem czasu, jaki pozostawał na wnoszenie protestów, co w skrajnej postaci mogło nawet skutkować niemożnością wniesienia protestu. Trzeci projekt - wniesiony do Marszałka Sejmu 4 grudnia 2014 r. - zakładał więcej zmian w procedurach wyborczych, w tym m.in. przezroczystą urnę wyborczą, inny sposób oddawania głosu (poprzez dowolny znak postawiony w kratce do głosowania, a nie tylko „x”), konieczność co najmniej dwukrotnego przeliczania głosów przez obwodowe komisje wyborcze, jak również konieczność ustalania przyczyn nieważności głosów ${ }^{50}$. Czwarty projekt, z dnia 23 lutego 2015 r. $^{51}$, obok powtarzania niektórych pomysłów w postaci przezroczystej urny wyborczej czy obowiązku ustalania przyczyn nieważności głosów, zawierał oryginalną propozycję zmiany systemu głosowania poprzez zastąpienie stawiania znaku „x” na kratce do głosowania naklejkami posiadającymi kody kreskowe. Projekt przewidywał dwa typy naklejek wyborczych - identyfikujących kartę do głosowania oraz służących wyborcom do oddania głosu. Projekt ten w opiniach (m.in. Sądu Najwyższego) został uznany za zbyt

47 Sondaż: co czwarty Polak uważa, że wybory zostaty sfatszowane, portal „Gazeta Prawna”, 25 XI 2014, [online] http://www.gazetaprawna.pl/artykuly/837692,sondaz-co-czwarty-polak-uwaza-ze-wybory-samorzadowe-zostaly-sfalszowane.html, 30 X 2015.

48 Poselski projekt ustawy o zmianie ustawy - Kodeks wyborczy, Sejm RP, VII kadencja, Druk nr 3053, Warszawa, 25 XI 2014.

49 Poselski projekt ustawy o zmianie ustawy - Kodeks wyborczy, Sejm RP, VII kadencja, Druk nr 3052, Warszawa, 27 XI 2014.

50 Poselski projekt ustawy o zmianie ustawy - Kodeks wyborczy, Sejm RP, VII kadencja, Druk nr 3099, Warszawa, 4 XII 2014.

51 Poselski projekt ustawy o zmianie ustawy - Kodeks wyborczy, Sejm RP, VII kadencja, Druk nr 3253, Warszawa, 23 II 2015. 
skomplikowany i zbyt kosztowny w realizacji oraz posiadający mankamenty o charakterze prawnym ${ }^{52}$. Ostatni projekt nowelizacji zgłoszony $\mathrm{w}$ formie obywatelskiego projektu ustawy w dniu 19 marca 2015 r. ${ }^{53}$ zakładał daleko idące zmiany w systemie wyborczym. Miały one polegać na wprowadzeniu możliwości nagrywania za pomocą urządzeń rejestrujących obraz i dźwięk przez mężów zaufania oraz prowadzenie transmisji online prac obwodowych komisji wyborczych, jak również istotne modyfikacje trybu powoływania składu Państwowej Komisji Wyborczej, której dziewięcioosobowy skład obejmowałby trzech sędziów zasiadających w niej z urzędu (Prezesów Trybunału Konstytucyjnego, Sądu Najwyższego i Naczelnego Sądu Administracyjnego) oraz sześciu sędziów powoływanych przez Prezydenta na wniosek klubów poselskich. Projekt przewidywał też inne zmiany, w tym m.in. likwidację instytucji głosowania korespondencyjnego i dwudniowego głosowania.

Natomiast dwa projekty zgłoszone przed wyborami samorządowymi 2014 r. odpowiednio 4 kwietnia 2014 r. $^{54}$ oraz 7 sierpnia 2014 r. ${ }^{55}$ - łączyło wprowadzenie kompleksowych regulacji dotyczących mężów zaufania w obwodowych komisjach wyborczych, którzy zostaliby wyposażeni w prawo m.in. utrwalania za pomocą urządzeń rejestrujących obraz i dźwięk prac obwodowych komisji wyborczych, przy czym drugi z nich - zgłoszony, jak wskazywali wnioskodawcy, pod wpływem wyborów do Parlamentu Europejskiego z dnia 25 maja 2014 r. - zawierał kilka regulacji, które pojawiały się w późniejszych projektach, w tym zapis o przezroczystej urnie wyborczej i opisane wyżej zmiany w składzie PKW.

Wybory samorządowe 2014 r. były również podłożem dyskusji o reformie samorządowego systemu wyborczego. Większość z umieszczonych w tej grupie projektów zamierzała bowiem do znacznej modyfikacji ówczesnego ustroju jednostek samorządu terytorialnego. Projekt zgłoszony 9 listopada 2012 r. zakładał ograniczenie możliwości pełnienia funkcji wójtów (burmistrzów, prezydentów miast) dłużej niż przez dwie kadencje $\mathrm{e}^{56}$. Jak wskazywali wnioskodawcy, obowiązujące regulacje nieprzewidujące żadnych ograniczeń w liczbie kadencji mogą sprzyjać kształtowaniu się patologicznych relacji we władzach gmin i jednocześnie ograniczają mechanizmy demokracji w samorządzie, blokując dostęp do funkcji wykonawczych ${ }^{57}$. Nie podejmując dyskusji z argumentami za i przeciw obowiązującym regulacjom, należy zwrócić uwagę, że długotrwałe pełnienie urzędu dotyczy stosunkowo dużej liczby osób pełniących funk-

52 Do Druku nr 3253, Sąd Najwyższy, Biuro Studiów i Analiz, BSA III - 021-77/15, Warszawa, 13 IV 2015.

53 Obywatelski projekt ustawy o zmianie ustawy - Kodeks wyborczy, Sejm RP, VII kadencja, Druk nr 3248, Warszawa, 19 III 2015.

54 Poselski projekt ustawy o zmianie ustawy - Kodeks wyborczy, Sejm RP, VII kadencja, Druk nr 2338, Warszawa, 4 IV 2014.

55 Poselski projekt ustawy o zmianie ustawy - Kodeks wyborczy, Sejm RP, VII kadencja, Druk nr 2873, Warszawa, 7 VIII 2014.

56 Poselski projekt ustawy o zmianie ustawy - Kodeks wyborczy, Sejm RP, VII kadencja, Druk nr 1015, Warszawa, 9 XI 2012.

57 Tamże, s. 3. 
cje wykonawcze w gminach. $Z$ danych podawanych przez wnioskodawców wynika, że $10,6 \%$ wójtów (burmistrzów, prezydentów miast) pełniło swoje funkcje od $1990 \mathrm{r}^{58}$ Kwestia ta niewątpliwie wymaga pogłębionej analizy i zapewne będzie powracać przed wyborami do samorządu terytorialnego VIII kadencji. Natomiast projekt zgłoszony na początku stycznia 2013 r. przewidywał reformę ustroju samorządowego powiatu i samorządowego województwa poprzez wprowadzenie bezpośrednich wyborów starosty powiatowego i marszałka na wzór wyborów przeprowadzanych w gminie ${ }^{59}$. Pro-

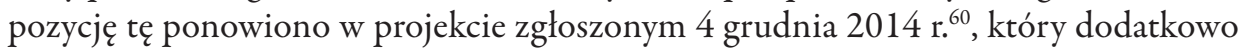
zakładał, iż wszystkie protesty wyborcze będzie rozpatrywał Sąd Apelacyjny w Warszawie. Postulat ten można umieścić $\mathrm{z}$ kolei w ramach szerszych dyskusji dotyczących możliwych reform samorządowych powiatów, choć jego założenia znacznie odbiegają od formułowanych w literaturze przedmiotów wariantów zmian w ustroju samorządu powiatowego. Czwarty projekt, z 4 grudnia 2014 r., zakładający również reformę administracji wyborczej ${ }^{61} \mathrm{w}$ obszarze samorządowego systemu wyborczego, zakładał częściowy powrót do założeń systemu wyborczego z ordynacji z 16 lipca 1998 r. w obszarze wyborów organów stanowiących, tzn. wprowadzenie w gminach powyżej 20 tys. mieszkańców oraz powiatach i województwach formuly proporcjonalnej opartej o metodę Sainte-Laguë, w gminach poniżej tej liczby stosowanie formuły większościowej opartej na jednomandatowych okręgach wyborczych. Według projektu metoda Sainte-Laguë byłaby również stosowana w wyborach do Sejmu. Pozostałe dwa projekty zmian w samorządowym prawie wyborczym nie wprowadzały już tak istotnych zmian. 22 lutego 2012 r. do Marszałka Sejmu wpłynął projekt ustawy, zgodnie z którym wyborcy uzyskaliby prawo dopisywania się do spisu wyborców w gminie między pierwszą i druga turą wyborów samorządowych, pod warunkiem stałego zamieszkiwania w danej gminie. Zmiana ta miała na celu wyeliminowanie praktyki celowych migracji „wyborczych” znanych z poprzednich elekcji ${ }^{62}$. Ostatni projekt tylko pośrednio dotyczył samorządowego systemu wyborczego, ale ze względu na charakter proponowanych zmian wart jest uwzględnienia, choć należy nadmienić, że w sensie formalnym nowelizował dwa przepisy Kodeksu wyborczego. Projekt ten zakładał zmianę reguł określających uzyskiwanie przez gminę statusu miasta na prawach powiatu. Status ten mogłyby bowiem uzyskać gminy liczące co najmniej 70 tys. mieszkańców i te, które z dniem 31 grudnia 1998 r. przestały być siedzibą wojewody i nie zdecydowały się na przyjęcie praw powiatu. Jak podnosili wnioskodawcy, zmiana ta dotyczyła trzech miast (Piły, Ciechanowa i Sieradza) i wywołałaby pewne drobne modyfikacje w sferze wyborów.

\section{Tamże.}

59 Poselski projekt ustawy o zmianie ustawy - Kodeks wyborczy i niektórych innych ustaw, Sejm RP, VII kadencja, Druk nr 1438, Warszawa, 15 I 2013.

60 Poselski projekt ustawy o zmianie ustawy - Kodeks wyborczy i niektórych innych ustaw, Sejm RP, VII kadencja, Druk nr 3185, Warszawa, 4 XII 2014.

${ }_{61}$ Poselski projekt ustawy o zmianie ustawy - Kodeks wyborczy, Sejm RP, VII kadencja, Druk nr 3099, Warszawa, 4 XII 2014.

62 Tamże, s. 3-4. 
Ostatni z projektów umieszczony w grupie „reform” systemu wyborczego, będący przedmiotem prac Sejmu VII kadencji, wprowadzał przede wszystkim zakaz prowadzenia kampanii wyborczej na terenach kościołów i miejsc kultu religijnego innych związków wyznaniowych, jak również w urzędach administracji publicznej i na terenach zakładów pracy, kiedy naruszałoby to ich normalne funkcjonowanie ${ }^{63}$. Co ciekawe, jak podnosili wnioskodawcy, pośrednim celem projektu było zrealizowanie konstytucyjnej zasady neutralności i autonomii kościołów i związków wyznaniowych, a w dołączonej do projektu opinii Episkopatu Polski wnioskowano o odrzucenie projektu w całości z powodu nierespektowania przez projekt tej samej zasady ${ }^{64}$.

Pięć projektów nowelizacji Kodeksu wyborczego rozpatrywanych w Sejmie VII kadencji mieści się w grupie zmian „modernizacyjnych”, przy czym w praktyce liczbę propozycji można ograniczyć do czterech, ponieważ dwa projekty zawierały zbliżone do siebie rozwiązania i były w pracach legislacyjnych rozpatrywane wspólnie. Zakładały też daleko idące zmiany w procesie konstruowania list wyborczych w wyborach opartych na formule proporcjonalnej i choć stanowiły kontynuację zmian wdrożonych wraz z kodyfikacją prawa wyborczego, zasługują na umieszczenie w tej kategorii zmian. Dotyczyły one wprowadzonych w $2011 \mathrm{r}$. tzw. kwot płci, zakładających, że zarówno kobiety, jak i mężczyźni muszą stanowić co najmniej 35\% wszystkich kandydatów na listach ${ }^{65}$. Negatywna ocena praktyki konstruowania list wyborczych w wyborach do Sejmu przeprowadzonych w 2011 r., polegająca co prawda na realizacji wymogu kwotowego, ale cechująca się umieszczaniem kobiet na dalszych miejscach niż mężczyzn, spowodowała, że zaczęto w stosunku do tego rozwiązania wysuwać dodatkowe postulaty ${ }^{66}$ polegające na zastąpieniu powyższych kwot płci rzeczywistym parytetem (czyli równym udziałem obu płci na listach) oraz wprowadzeniem zasady naprzemienności polegającej na tym, że osoby tej samej płci nie mogą zajmować sąsiednich miejsc na listach wyborczych. Projekt nowelizacji zgłoszony 10 października 2012 r. $^{67}$ przewidywał obie nowości, a projekt z 28 stycznia 2013 r. ograniczał się tylko do zasady naprzemienności przy zastosowaniu dotychczasowego systemu kwotowego ${ }^{68}$. Co ciekawe, propozycje zawarte w projektach spotykały z poparciem większości posłów - w trakcie połączonych prac Komisji Samorządu Terytorialnego i Polityki Regionalnej oraz Komisji Sprawiedliwości i Praw Człowieka w dniu 20 listopada 2013 r. podjęto decyzję o wspólnym rozpatrywaniu obu projektów ${ }^{69}$ - ale prace nad nimi ostatecznie zatrzy-

63 Poselski projekt ustawy o zmianie ustawy - Kodeks wyborczy, Sejm RP, VII kadencja, Druk nr 1885, Warszawa, 6 IX 2013.

64 Tamże, s. 11-13.

65 D. Sieklucki, Dynamika..., s. 141-143.

66 M. Fuszara, Kwoty, listy wyborcze i równość ptci w wyborach parlamentarnych 2011 roku, Warszawa, 2012, s. 27.

67 Poselski projekt ustawy o zmianie ustawy - Kodeks wyborczy z dnia 5 stycznia 2011 r., Sejm RP, VII kadencja, Druk nr 1146, Warszawa, 10 X 2012.

68 Poselski projekt ustawy o zmianie ustawy - Kodeks wyborczy, Sejm RP, VII kadencja, Druk nr 1151, Warszawa, 28 I 2013.

69 Petny zapis przebiegu posiedzenia Komisji Samorzadu Terytorialnego i Polityki Regionalnej (nr 213) i Komisji Sprawiedliwości i Praw Cztowieka (nr 139), Sejm RP, VII kadencja, Kancelaria Sejmu, 2013, s. 3. 
mały się na etapie drugiego czytania 25 czerwca $2014 \mathrm{r}^{70}$ Zapewne było to w pewnym stopniu powiązane $\mathrm{z}$ dużymi konsekwencjami wprowadzenia obu nowości oraz pewną dyskusyjnością samej instytucji parytetu, o czym świadczy przebieg dyskusji w komisjach w dniu 5 czerwca 2014 r. $^{71}$

Nie zostały również dokończone prace nad projektem zgłoszonym 26 czerwca 2013 r. $^{72}$ zakładającym całkowitą likwidację finansowania partii politycznych z budżetu państwa w formie subwencji i dotacji uzyskiwanych z tytułu osiągniętych wyników w wyborach do Sejmu, Senatu i Parlamentu Europejskiego. W jego przypadku aktywność posłów ograniczyła się do przeprowadzenia pierwszego czytania, podczas którego podjęto decyzję o przekazaniu projektu do Komisji Nadzwyczajnej. Należy zwrócić uwagę, że proponowana zmiana dotyczyła przede wszystkim sposobu finansowania partii politycznych, a nie zmiany systemu wyborczego, ale z uwagi na swoją treść oraz dokonywanie nowelizacji przepisów Kodeksu wyborczego wymaga uwzględnienia w artykule. Sam projekt był wprawdzie ograniczony w zakresie wprowadzanych regulacji - po prostu likwidował bardzo ważne źródło dochodów partii politycznych, bez wprowadzania jakichkolwiek innych zmian w systemie finansów partyjnych - jednak jego ewentualne uchwalenie miałoby duże konsekwencje dla przebiegu wyborów. Nie tylko dlatego, że partie politycznie zostałyby zmuszone do wewnętrznej reorganizacji, ale również z tego powodu, że projektowana zmiana wymagałaby (czego nie uwzględnili wnioskodawcy) istotnego przeformułowania szeregu przepisów dotyczących prowadzenia kampanii wyborczych, zakładania komitetów wyborczych i składania sprawozdań z prowadzonej agitacji wyborczej.

Interesującą zmianę przewidywała nowelizacja Kodeksu wyborczego wniesiona do Marszałka Sejmu 21 października 2013 r., zakładająca uzupełnienie go o przepis następującej treści: $w$ okresie 7 dni przed dniem gtosowania aź do momentu jego zakończenia zabrania się publikowania lub podawania do publicznej wiadomości w inny sposób wyników przedwyborczych badań, sondaży opinii publicznej dotyczacych przewidywanych zachowan wyborczych lub wyniku wyborów oraz wyników sondazy wyborczych przeprowadzanych $w$ dniu gtosowania ${ }^{73}$. Zmiana ta - niewątpliwie podyktowana pozytywnymi przesłankami - mogłaby stworzyć wyborcom lepsze warunki do podjęcia decyzji wyborczych, bez kierowania się bezpośrednio notowaniami partii politycznych i kandydatów w badaniach opinii publicznych, szczególnie że w okresach przedwyborczych niekiedy wyniki badań służą jako narzędzie walki o głosy wyborców. Zasadniczym problemem jednak jest, czy w erze powszechnego dostępu do technologii komunikacyjno-informacyjnych taki zakaz jest w ogóle egzekwowalny. Zwraca się bowiem uwagę, że w dobie Internetu kategoria tzw. ciszy wyborczej obecnie zasadniczo

70 Przebieg prac na projektem ustawy, Druk nr 1146, [online] http://www.sejm.gov.pl/Sejm7.nsf/PrzebiegProc.xsp?nr=1146, 2 XI 2015.

71 Tamże.

72 Poselski projekt ustawy o zmianie ustawy o partiach politycznych oraz o zmianie ustawy Kodeks wyborczy, Sejm RP, VII kadencja, Druk nr 1649, Warszawa, 26 VI 2013.

73 Poselski projekt ustawy o zmianie ustawy - Kodeks wyborczy, Sejm RP, VII kadencja, Druk nr 2019, Warszawa, 21 X 2013. 
traci sen ${ }^{74}$. Prace nad tym projektem nie zostały zakończone, choć, jak wspominałem, komisja zarekomendowała jego odrzucenie.

Ostatni projekt „modernizacyjny” zakładał obniżenie granicy cenzusu czynnego prawa wyborczego do 16 lat w wyborach do Parlamentu Europejskiego ${ }^{75}$. Ograniczenie zmiany tylko do PE było uzasadnione tym, że tylko w przypadku tej instytucji możliwa jest modyfikacja regulacji dotyczących wieku wyborcy bez zmiany przepisów Konstytucji ${ }^{76}$. Projekt ten został wprawdzie odrzucony na etapie pierwszego czytania 21 lutego 2014 r. zdecydowaną większością głosów (za odrzuceniem głosowało 374 posłów, przeciw 59, a 1 wstrzymał się od głosu $)^{77}$, ale stanowi jednocześnie wyraz pewnych tendencji w systemach wyborczych współczesnych demokracji. Warto również zwrócić uwagę, że problematyka obniżania granicy wieku w zakresie korzystania z czynnego prawa wyborczego ma już w Polsce pewną tradycję (pierwsze propozycje wysuwano w 2013 r.) i jest przedmiotem dyskusji. Przyznawanie prawa głosu osobom poniżej 18 roku życia jest uzasadniane starzeniem się społeczeństw, powodującym, że starsi wyborcy są nadreprezentowani w ogóle wyborców, oraz arbitralnością granicy 18 lat (młodzi ludzie uzyskuję różne uprawnienia na różnych etapach życia). Kontrargumenty sprowadzają się do wskazywania na pewną niedojrzałość młodego wyborcy, połączoną z jego niesamodzielnością (uleganie wpływom środowiska społecznego, reklamie i modom $)^{78}$.

Analiza zmian oraz projektów zmian Kodeksu wyborczego w Sejmach VI i VII kadencji pozwala na wyciągnięcie pięciu wniosków, odnoszących się jednocześnie do sformułowanych na wstępie problemów badawczych.

Po pierwsze - w świetle liczby rozpatrywanych nowelizacji uzasadniona jest teza, iż polski system wyborczy znajduje się w permanentnym procesie zmian i należy się spodziewać, że w Sejmie VIII kadencji oraz zapewne w okresie późniejszym będą nadal inicjowane prace nad zmianami w prawie wyborczym ${ }^{79}$. Zakładana podczas kodyfikacji prawa wyborczego jego stabilizacja nie znajduje dotychczas potwierdzenia w praktyce i trudno oczekiwać, by mogła zmienić się w przyszłości.

Po drugie - łatwo można zauważyć, że zdecydowana większość propozycji zmian (zarówno uchwalonych, jak i nieuchwalonych) ma charakter sytuacyjny, tzn. albo jest

74 M. Musial-Karg, Cisza wyborcza w dobie Internetu, „Przegląd Sejmowy” 2013, nr 3(116), s. 40.

75 Poselski projekt ustawy o zmianie ustawy - Kodeks wyborczy, Sejm RP, VII kadencja, Druk nr 2110, Warszawa, 11 XII 2013.

76 D. Sieklucki, Dynamika..., s. 90.

77 Przebieg prac nad projektem ustawy, Druk nr 2110, [online] http://www.sejm.gov.pl/Sejm7.nsf/PrzebiegProc.xsp?nr=2110, 2 XI 2015.

78 M. Waszak, J. Zbieranek, Propozycja obniżenia wieku czynnego prawa wyborczego do 16 lat. Wybrane zagadnienia, Warszawa 2010, s. 6-10.

79 W ciągu pierwszych niespełna pięciu miesięcy działania Sejmu VIII kadencji do Marszałka Sejmu wpłynęły, w dniu 13 I 2016 r., dwa projekty zmian w Kodeksie wyborczym. Oba zostały odrzucone na etapie pierwszego czytania. Jeden zakładał zmiany w systemie finansowania partii politycznych i przede wszystkim wprowadzał zmiany w Ustawie o partiach politycznych, a drugi zakładał likwidację tzw. ciszy wyborczej. 
przygotowywana pod konkretne głosowanie, albo została sformułowana na podstawie doświadczeń przeprowadzonej elekcji. Stąd można oczekiwać, że intensyfikacja prac nad zmianami w prawie wyborczym będzie postępować - co znajduje potwierdzenie od początku lat $90 .^{80}$ - w miarę zbliżania się terminu wyborów. Wspomniana „sytuacyjność" ma również tę konsekwencję, że część projektów albo sprawia wrażenie nie do końca przemyślanych, albo nie została należycie przygotowana od strony formalnej, czego dobitnym przykładem jest propozycja likwidacji finansowania partii politycznych z budżetu państwa. Trzeba również przypomnieć, że sporo propozycji zmian w systemie wyborczym dotyczyło administracji wyborczej, a zostały one sformułowane na bazie doświadczeń wyborów samorządowych z 2014 r. Dyskusje nad zmianami w administracji wyborczej powinny być oczywiście prowadzone, szczególnie że w literaturze przedmiotu podnosi się szereg jej mankamentów ${ }^{81}$, ale nie mogą one wiązać się - co widać w tle zgłaszanych projektów - z podważaniem uczciwości przebiegu wyborów i formułowaniem szkodliwych dla instytucji przeprowadzających wybory (i tym samym polskiej demokracji) opinii o celowych i świadomych manipulacjach w procesie wyborczym.

Po trzecie - wśród trzech wyodrębnionych dla celów analitycznych kategorii zmian widać zdecydowaną przewagę „korekt” i „reform” nad „modernizacją”. Oczywiście wynika to zasadniczo, jak wskazywałem, z postrzegania działania systemu wyborczego w perspektywie krótkoterminowej i z działań obliczonych na szybki efekt w nadchodzącej elekcjii ${ }^{82}$. Dlatego też w odniesieniu do przyszłości polskiego systemu wyborczego można wyrazić postulat: mniej reform, a więcej modernizacji, pomimo że ma on charakter życzeniowy. Warto również zauważyć, że zgłaszane propozycje dotyczą różnych elementów systemu wyborczego i z reguły mają wycinkowy (fragmentaryczny) charakter.

Po czwarte - w moim przekonaniu modernizacja powinna oznaczać, że przedmiotem dyskusji i prac legislacyjnych powinny stać się trzy główne problemy (wyzwania). Pierwszy to wdrażanie nowoczesnych technologii komunikacyjno-informacyjnych (ICT), co nie tylko pozwoliłoby uniknąć kryzysu, jaki wybuchł podczas liczenia głosów jesienią 2014 r., ale również pozwoliłoby Polsce nadgonić rosnący dystans w tym obszarze do innych państw demokratycznych. Drugi - to wzmacnianie zainteresowania wyborami i tym samym stymulowanie wzrostu frekwencji. Działania te oczywiście można łączyć z wdrażaniem ICT, ale mogą one obejmować także inne zmiany. War-

80 Szerzej o tej tendencji piszę w monografii D. Sieklucki, Dynamika..., s. 249-253.

81

B. Michalak, J. Zbieranek, Administracja wyborcza w kryzysie. Analiza i rekomendacje na przysztośc, [w:] J. Flis i in., Co stato się 16 listopada?..., s. 9-30.

82 W tym ujęciu projekt obniżenia granicy wieku do czynnego prawa wyborczego pomimo umieszczenia w grupie zmian „modernizacyjnych” miał charakter sytuacyjny, ponieważ zgłaszające go ugrupowanie (Ruch Palikota) liczyło, że przyniesie mu zwiększone poparcie w wyborach do Parlamentu Europejskiego z 2014 r., ale ze względu na swój charakter, tzn. wprowadzanie istotnego novum do polskiego systemu wyborczego, mogącego z czasem (oczywiście pod warunkiem uchwalenia) stanowić wstęp do dalszych zmian. Ponadto obniżanie granicy wieku w zakresie czynnego prawa wyborczego jest jednym z aktualnych obszarów dyskusji nad systemami wyborczymi współczesnych demokracji. 
to nadmienić, że wyraźnym krokiem do przodu w tym obszarze było wprowadzenie w szerszym zakresie głosowania korespondencyjnego. Trzeci - to wzmacnianie mechanizmów reprezentacji. Aktualne dyskusje - prowadzone na tle kampanii wyborczych 2015 r. - łączą je z jednomandatowymi okręgami wyborczymi, choć w moim przekonaniu w dyskusjach należy wykroczyć poza kwestie formuły wyborczej i całościowo podjąć analizę procedur wyborczych związanych również ze zgłaszaniem kandydatów czy specyfiką wyborów samorządowych.

Po piąte, na koniec, należy również odnieść się do postawionego na wstępie pytania o przyczyny braku stabilizacji prawa wyborczego pomimo jego kodyfikacji. Wynika to, jak sądzę, z trzech powiązanych ze sobą przyczyn. Pierwsza dotyczy tego, że uchwalenie Kodeksu wyborczego nie przyniosło żadnych zasadniczych zmian o charakterze modernizacyjnym. Stały się one przedmiotem refleksji i prac dopiero po przyjęciu tego dokumentu przez obie izby parlamentu. Druga to niewprowadzenie do polskiego systemu wyborczego jakichkolwiek rozwiązań zabezpieczających prawo wyborcze przed częstymi, nieprzemyślanymi zmianami w postaci znanej z innych państw reguły, zgodnie z którą zmiana w prawie wyborczym wchodzi w życie dopiero po wyborach, przed którymi została uchwalona. Zasadę tę można wyrazić poprzez inne formuly prawne i ewentualne wyjątki dotyczące zmian wynikających z obiektywnych przyczyn (np. koniecznych korekt granic okręgów wyborczych z powodu procesów migracyjnych ludności). Trzecia obejmuje podnoszone w literaturze przedmiotu zastrzeżenia co do jakości kodyfikacji, de facto polegającej na skompilowaniu w szybkim tempie pięciu poprzednio obowiązujących ordynacji wyborczych w jeden dokument, co niestety wykluczało - jak pisze Krzysztof Skotnicki - rzetelną i pogłębioną analizę prawa wyborczego, z uwzględnieniem koniecznych zmian, a skoncentrowano się na rozpatrywaniu kolejnych artykułów ${ }^{83}$. Jakość kodyfikacji dobrze ilustruje późniejsza liczba korekt Kodeksu, jak również zaskarżenie go do Trybunału Konstytucyjnego, który uchylił niektóre jego przepisy wspominanym z wyrokiem z 20 lipca $2011 \mathrm{r}^{84}$

Last, but not least - można więc stwierdzić, że Kodeks wyborczy nadal będzie korygowany i reformowany, choć odpowiedź na pytanie o główne kierunki zmian przyniosą dopiero kolejne lata. Można wprawdzie oczekiwać kontynuacji niektórych działań z przeszłości, ale zapewne pojawią się też nowe tendencje. Najważniejsze, by ewentualnie zmiany zostały poprzedzone rzetelną analizą i nie sprowadzały się, jak często miało to już miejsce, do formułowania nieprzemyślanych i niekiedy niepotrzebnych propozycji.

83 K. Skotnicki, Przebieg prac..., s. 33.

84 Jako egzemplifikację jakości kodyfikacji prawa wyborczego można przytoczyć instytucję dwudniowego głosowania. Wprowadzono ją w pierwotnej wersji Kodeksu w wyborach wszystkich instytucji, ale Trybunał Konstytucyjny wyrokiem z 20 VII 2011 r. uznał, że nie jest możliwe przeprowadzanie dwudniowego głosowania w wyborach prezydenckich i parlamentarnych, pozostawił je jednak w wyborach samorządowych i do PE. Nie jest to jednak możliwe, ponieważ art. 371 ust. 1 oraz art. 331 ust. 2 Kodeksu stanowi, że datę wyborów w obu powyższych przypadkach wyznacza się na dzień wolny od pracy. Dwudniowe głosowanie będzie więc możliwe dopiero po korekcie obu przepisów. Znamienne jest, że do końca kadencji Sejmu wybranego w 2011 r. w ogóle nie podjęto prac w tym zakresie. 


\section{BIBLIOGRAFIA}

\section{Źródła}

Do Druku nr 3253, Sąd Najwyższy, Biuro Studiów i Analiz, BSA III - 021-77/15, Warszawa, 13 IV 2015.

Obwieszczenie Marszatka Sejmu Rzeczypospolitej Polskiej z dnia 17 stycznia 2012 r. w sprawie ogtoszenia jednolitego tekstu uchwaty Sejmu Rzeczypospolitej Polskiej - Regulamin Sejmu Rzeczypospolitej Polskiej, M.P. 2012, poz. 32.

Obwieszczenie Państwowej Komisji Wyborczej z dnia 11 maja 2015 r. o wynikach gtosowania i wyniku wyborów Prezydenta Rzeczypospolitej Polskiej, zarządzonych na dzień 10 maja 2015 r., Dz.U. 2015, poz. 650.

Obwieszczenie Państwowej Komisji Wyborczej z dnia 25 maja 2015 r. o wynikach ponownego gtosowania i wyniku wyborów Prezydenta Rzeczypospolitej Polskiej, Dz.U. 2015, poz. 725.

Obywatelski projekt ustawy o zmianie ustawy - Kodeks wyborczy, Sejm RP, VII kadencja, Druk nr 3248, Warszawa, 19 III 2015.

Petny zapis przebiegu posiedzenia Komisji Samorzadu Terytorialnego i Polityki Regionalnej (nr 213) i Komisji Sprawiedliwości i Praw Cztowieka (nr 139), Sejm RP, VII kadencja, Kancelaria Sejmu, 2013.

Poselski projekt ustawy o zmianie ustawy - Kodeks wyborczy, Sejm RP, VII kadencja, Druk nr 318, Warszawa, 22 II 2012.

Poselski projekt ustawy o zmianie ustawy - Kodeks wyborczy, Sejm RP, VII kadencja, Druk nr 1015, Warszawa, 9 XI 2012.

Poselski projekt ustawy o zmianie ustawy - Kodeks wyborczy, Sejm RP, VII kadencja, Druk nr 1151, Warszawa, 28 I 2013.

Poselski projekt ustawy o zmianie ustawy - Kodeks wyborczy, Sejm RP, VII kadencja, Druk nr 1885, Warszawa, 6 IX 2013.

Poselski projekt ustawy o zmianie ustawy - Kodeks wyborczy, Sejm RP, VII kadencja, Druk nr 2019, Warszawa, 21 X 2013.

Poselski projekt ustawy o zmianie ustawy - Kodeks wyborczy, Sejm RP, VII kadencja, Druk nr 2110, Warszawa, 11 XII 2013.

Poselski projekt ustawy o zmianie ustawy - Kodeks wyborczy, Sejm RP, VII kadencja, Druk nr 2338, Warszawa, 4 IV 2014.

Poselski projekt ustawy o zmianie ustawy - Kodeks wyborczy, Sejm RP, VII kadencja, Druk nr 2873, Warszawa, 7 VIII 2014.

Poselski projekt ustawy o zmianie ustawy - Kodeks wyborczy, Sejm RP, VII kadencja, Druk nr 3052, Warszawa, 27 XI 2014.

Poselski projekt ustawy o zmianie ustawy - Kodeks wyborczy, Sejm RP, VII kadencja, Druk nr 3053, Warszawa, 25 XI 2014.

Poselski projekt ustawy o zmianie ustawy - Kodeks wyborczy, Sejm RP, VII kadencja, Druk nr 3099, Warszawa, 4 XII 2014.

Poselski projekt ustawy o zmianie ustawy - Kodeks wyborczy, Sejm RP, VII kadencja, Druk nr 3253, Warszawa, 23 II 2015. 
Poselski projekt ustawy o zmianie ustawy - Kodeks wyborczy, Sejm RP VII kadencja, Druk nr 3605, Warszawa, 15 V 2015.

Poselski projekt ustawy o zmianie ustawy - Kodeks wyborczy i niektórych innych ustaw, Sejm RP, VII kadencja, Druk nr 377, Warszawa, 22 III 2012.

Poselski projekt ustawy o zmianie ustawy - Kodeks wyborczy i niektórych innych ustaw, Sejm RP, VII kadencja, Druk nr 1438, Warszawa, 15 I 2013.

Poselski projekt ustawy o zmianie ustawy - Kodeks wyborczy i niektórych innych ustaw, Sejm RP, VII kadencja, Druk nr 3185, Warszawa, 4 XII 2014.

Poselski projekt ustawy o zmianie ustawy - Kodeks wyborczy i niektórych innych ustaw, Sejm RP, VII kadencja, Druk nr 2337, Warszawa, 12 III 2014.

Poselski projekt ustawy o zmianie ustawy - Kodeks wyborczy oraz niektórych innych ustaw, Sejm RP, VII kadencja, Druk nr 1786, Warszawa, 24 VII 2013.

Poselski projekt ustawy o zmianie ustawy - Kodeks wyborczy oraz ustawy Przepisy wprowadzające ustawe - Kodeks wyborczy, Sejm RP, VI kadencja, Druk nr 3813, Warszawa, 14 I 2011.

Poselski projekt ustawy o zmianie ustawy - Kodeks wyborczy z dnia 5 stycznia 2011 r., Sejm RP, VII kadencja, Druk nr 1146, Warszawa, 10 X 2012.

Poselski projekt ustawy o zmianie ustawy o partiach politycznych oraz o zmianie ustawy Kodeks wyborczy, Sejm RP, VII kadencja, Druk nr 1649, Warszawa, 26 VI 2013.

Postanowienie Prezydenta Rzeczypospolitej Polskiej z dnia 17 czerwca 2015 r. o zarządzeniu ogólnokrajowego referendum, Dz.U. 2015, poz. 852.

Przebieg prac na projektem ustawy, Druk nr 1146, [online] http://www.sejm.gov.pl/Sejm7.nsf/ PrzebiegProc.xsp?nr=1146.

Przebiegprac nad projektem ustawy, Druk nr 2110, [online] http://www.sejm.gov.pl/Sejm7.nsf/ PrzebiegProc.xsp?nr=2110.

Rządowy projekt ustawy - Prawo pocztowe, Sejm RP, VII kadencja, Druk nr 801, Warszawa, 8 X 2012.

Senacki projekt ustawy o zmianie ustawy - Kodeks wyborczy, Sejm RP, VII kadencja, Druk nr 1350, Warszawa, 18 IV 2013.

Sprawozdanie Komisji Nadzwyczajnej do spraw zmian w kodyfikacjach o poselskim projekcie ustawy o zmianie ustawy - Kodeks wyborczy, Sejm RP, VII kadencja, Druk nr 3088, Warszawa, 15 I 2015.

Sprawozdanie stenograficzne z 80. posiedzenia Sejmu RP $w$ dniu 26 listopada 2014 r., Warszawa 2014.

Ustawa z dnia 5 stycznia 2011 r. - Kodeks wyborczy, Dz.U. 2011, nr 21, poz. 112.

Ustawa z dnia 3 lutego 2011 r. o zmianie ustawy - Kodeks wyborczy, Dz.U. 2011, nr 26, poz. 134.

Ustawa z dnia 1 kwietnia 2011 r. o zmianie ustawy - Ordynacja wyborcza do Sejmu Rzeczypospolitej Polskiej i do Senatu Rzeczypospolitej Polskiej oraz ustawy - Kodeks wyborczy, Dz.U. 2011, nr 94, poz. 550 .

Ustawa z dnia 15 kwietnia 2011 r. o zmianie ustawy - Kodeks wyborczy oraz ustawy - Przepisy wprowadzajace ustawe - Kodeks wyborczy, Dz.U. 2011, nr 102, poz. 588.

Ustawa z dnia 26 maja 2011 r. o zmianie ustawy o samorządzie gminnym oraz niektórych innych ustaw, Dz.U. 2011, nr 134, poz. 777.

Ustawa z dnia 27 maja 2011 r. o zmianie ustawy - Kodeks wyborczy oraz ustawy - Przepisy wprowadzajace ustawe - Kodeks wyborczy, Dz.U. 2011, nr 147, poz. 881. 
Ustawa z dnia 31 sierpnia 2011 r. o zmianie ustawy - Kodeks wyborczy oraz niektórych innych ustaw, Dz.U. 2011, nr 217, poz. 1281.

Ustawa z dnia 13 lipca 2012 r. o zmianie ustawy o dziatach administracji rządowej oraz niektórych innych ustaw, Dz.U. 2012, poz. 951.

Ustawa z dnia 12 października 2012 r. o zmianie ustawy - Przepisy wprowadzające ustawe - Kodeks wyborczy, Dz.U. 2012, poz. 1399.

Ustawa z dnia 23 listopada 2012 r. Prawo pocztowe, Dz.U. 2012, poz. 1529.

Ustawa z dnia 10 stycznia 2014 r. o zmianie ustawy - Kodeks wyborczy, Dz.U. 2014, poz. 179.

Ustawa z dnia 10 stycznia 2014 r. o zmianie ustawy - Kodeks wyborczy, Dz.U. 2014, poz. 180.

Ustawa z dnia 10 lipca 2015 r. o zmianie ustawy - Kodeks wyborczy, Dz.U. 2015, poz. 1044.

Ustawa z dnia 25 czerwca 2015 r. o zmianie ustawy - Kodeks wyborczy, Dz.U. 2015, poz. 1043.

Wyrok Trybunatu Konstytucyjnego z dnia 20 lipca 2011 r. sygn. akt K 9/11, Dz.U. 2011, nr 149, poz. 889 .

\section{Literatura}

Fuszara M., Kwoty, listy wyborcze i równość ptci w wyborach parlamentarnych 2011 roku, Warszawa 2012.

korekta, [w:] Stownik wyrazów obcych i zwrotów obcojezycznych Wtadystawa Kopalińskiego, [online] http://www.slownik-online.pl/kopalinski/743361D15E06F5F3C12565E9005557 E1.php.

korekta, [w:] Stownik jezyka polskiego PWN, [online] http://sjp.pwn.pl/sjp/korekta;2474027.html. Michalak B., Zbieranek J., Administracja wyborcza w kryzysie. Analiza i rekomendacje na przysztośc, [w:] J. Flis i in., Co stato sie 16 listopada? Wybory samorządowe 2014 r., Warszawa 2015.

modernizacja, [w:] Stownik wyrazów obcych i zwrotów obcojezycznych Wtadystawa Kopalinskiego, [online] http://www.slownik-online.pl/kopalinski/F065D59D113D2D41C12565DB005AFA8E.php.

modernizacja, [w:] Stownik jezyka polskiego PWN, [online] http://sjp.pwn.pl/szukaj/modernizacja.html.

Musiał-Karg M., Cisza wyborcza w dobie Internetu, „Przegląd Sejmowy” 2013, nr 3(116).

Patrzałek A., Skrzydło W., Cele i zasady kodyfikacji prawa wyborczego w Polsce, „Przegląd Sejmowy” 1997, nr 2(19).

reforma, [w:] Stownik wyrazów obcych i zwrotów obcojezycznych Wtadystawa Kopalińskiego, [online] http://www.slownik-online.pl/kopalinski/2EAFA44F187E7CE9C12565850074 CCB9.php.

reforma, [w:] Stownik jezyka polskiego PWN, [online] http://sjp.pwn.pl/szukaj/reforma.html. Rychard A., Wprowadzenie, [w:] J. Flis i in., Co stato się 16 listopada? Wybory samorzadowe 2014 r., Warszawa 2015.

Sieklucki D., Dynamika systemu wyborczego III Rzeczypospolitej na tle historycznym, Kraków 2015.

Skotnicki K., Przebieg prac nad kodeksem wyborczym, [w:] Kodeks wyborczy. Wstępna ocena, red. tenże, Warszawa 2011.

Sokala A., Ordynacja wyborcza do Sejmu Rzeczypospolitej Polskiej i do Senatu Rzeczypospolitej Polskiej z dnia 12 kwietnia 2001 r. - wstęp i krótki komentarz, Toruń 2001. 
Sondaż: co czwarty Polak uważa, że wybory zostaty sfatszowane, portal „Gazeta Prawna”, 25 XI 2014, [online] http://www.gazetaprawna.pl/artykuly/837692,sondaz-co-czwarty-polak-uwaza-ze-wybory-samorzadowe-zostaly-sfalszowane.html, 30 X 2015.

Waszak M., Zbieranek J., Propozycja obniżenia wieku czynnego prawa wyborczego do 16 lat. Wybrane zagadnienia, Warszawa 2010.

Wybory samorządowe 2014 r. Statystyki wyników głosowania, [online] http://pkw.gov.pl/ wizualizacja-wyborow-samorzadowych-samorzad-2014/wybory-samorzadowe-2014-r-statystyki-wynikow-glosowania.html, 20 X 2015.

Zbieranek J., Alternatywne procedury gtosowania w polskim prawie wyborczym - gwarancja powszechności wyborów czy mechanizm zwiększania frekwencji wyborczej?, Warszawa 2013.

Dr hab. Dominik SIEKLUCKI - doktor habilitowany nauk społecznych w zakresie nauk o polityce, adiunkt w Instytucie Nauk Politycznych i Stosunków Międzynarodowych Uniwersytetu Jagiellońskiego. Autor ponad 30 publikacji naukowych, w tym monografii naukowych Partie lewicy i centrolewicy w polskim systemie partyjnym. Aktywność SLD, PSL i UP na polskiej scenie politycznej (Wydawnictwo Uniwersytetu Jagiellońskiego, Kraków 2006) oraz Dynamika systemu wyborczego III Rzeczypospolitej na tle historycznym (Wydawnictwo Uniwersytetu Jagiellońskiego, Kraków 2015). Zajmuje się problematyką systemów politycznych, systemów wyborczych i administracją publiczną. 